\title{
Publisher Correction: Feasibility and coexistence of large ecological communities
}

Jacopo Grilli, Matteo Adorisio, Samir Suweis, György Barabás, Jayanth R. Banavar, Stefano Allesina

$\&$ Amos Maritan

Nature Communications 8:14389 doi: 10.1038/ncomms14389; Published 24 Feb 2017; Updated 13 Jul 2018

The original HTML version of this Article had an incorrect article number of ' 0 '; it should have been ' 14389 '. This has now been corrected in the HTML version of the Article. The PDF version was correct from the time of publication.

\footnotetext{
(c) ()

Open Access This article is licensed under a Creative Commons Attribution 4.0 International License, which permits use, sharing, adaptation, distribution and reproduction in any medium or format, as long as you give appropriate credit to the original author(s) and the source, provide a link to the Creative Commons license, and indicate if changes were made. The images or other third party material in this article are included in the article's Creative Commons license, unless indicated otherwise in a credit line to the material. If material is not included in the article's Creative Commons license and your intended use is not permitted by statutory regulation or exceeds the permitted use, you will need to obtain permission directly from the copyright holder. To view a copy of this license, visit http://creativecommons.org/licenses/by/4.0/
}

(C) The Author(s) 2018 